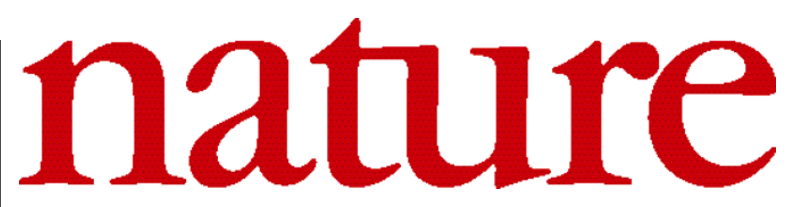

5 June 1997 Volume 387 Issue no 6633

\title{
Time for determination and hope in Russia
}

A new mood of optimism can be found in many parts of Russia's scientific community that has been absent for much of the past five years. But it must not be allowed to turn into complacency; many hurdles remain.

$\mathrm{N}$ o longer is the talk in Moscow laboratories solely of declining salaries and broken government promises - or even, on occasion, suicide. The prospect of real change is in the air as plans for the reform of Russian science become more realistic, and the need for radical change becomes more widely accepted.

Part of the new optimism is based on the government's declared determination to introduce much-needed changes in the way Russian science is run, and to try to ensure that its budget is protected. A decree issued at the beginning of last month, for example, set out a number of important reform measures, including the promise to establish procedures for assessing the scientific performance of government research institutions, and closing those that fail to come up to scratch. And the science budget has been 'ring-fenced' against cuts during the year as an essential component of public spending. On past experience, government promises involving money should be viewed sceptically. The good news lies in its intention to focus resources more productively.

In this, the role of the Russian Academy of Sciences will be crucial. There are signs that the academy is prepared to grasp the nettle of change, albeit somewhat gingerly. Last week, it accepted pressure from the government by electing a number of 'young' academicians - meaning under 55 for full members, and under 50 for corresponding members - in an attempt to help attract new blood into influential positions in the research system (see page 535). More enthusiastic has been the academy's response to the government's decision that its individual institutes be allowed to rent out land and redundant facilities, if the income is used to purchase scientific equipment and to meet other infrastructure needs.

\section{Hidebound}

But too much of Russian science remains hidebound by outdated bureaucratic rules, as well as tensions and distrust between the state and much of the research community which, ironically for a country which has in the past invested so heavily in science, remains one of the deepest and most damaging legacies of the Communist era.

At the same time, new tensions have been created by some of the early reforms of the Yeltsin era. Many of these, such as the Russian Foundation for Fundamental Research and the now-defunct International Science Foundation set up by the financier George Soros, have attempted quite properly to establish new traditions of strict peer review, but have found it easier to do this outside the traditional channels. This has inevitably created tension with those who claim that the need is to reform the current system, not undermine it.

The result has been something of a backlash, with a shift in power back to the academy, and the dangers that this contains. Academy officials are correct to emphasize that the development of science in Russia, as indeed in any modern state, cannot be left to the private sector and market forces alone. What is needed now is a sustained and strategically targeted investment, coordinated but not controlled by the government, to build and maintain the country's scientific infrastruc- ture. As the pressure on salaries subsides, for example, the main difficulty facing many laboratories, keen to meet international levels of scientific competence, is the absence of adequate research equipment.

As the government has recognized in last month's decree, achieving such targeted investment will mean some difficult decisions. The danger is that the academy will become excessively concerned with its own survival and the maintenance of its anachronistic system of privileges. As a result, it could well fail to find the courage to take what can often be painful courses of action, including the closure of unproductive institutes and the elimination of research groups whose output does not meet international standards.

Yet it is no longer sufficient for the academy to boast of its intellectual prowess on the basis primarily of its past achievements and quantitative measurements of published research papers. Money for investment in science is scarce in the modern world, perhaps in Russia more than anywhere else. It can afford to support only that which meets international standards of quality.

\section{Continued support}

To achieve this, Russian science needs continued support from the West. Here the efforts of the European organization INTAS, and the Civilian Research and Development Fund, set up under the broad umbrella of US/Russian cooperation agreements, continue to have an invaluable role to play.

But such actions are unlikely to achieve long-lasting change unless they are combined with political support for those reformers in government who are trying to introduce more flexibility, accountability and openness into the whole of the research system. Much was achieved in this direction by the former science minister, Boris Saltykov, who, before being replaced after last year's elections, sketched out a vision of how Russian science could rise again if — and only if — it was prepared to adopt practices that have proved successful in other countries.

The spirit of Saltykov's reforms lives on in the reforms introduced last month. One of the most important clauses is one that urges both the ministry of economics and the ministry of science, currently combined with telecommunications, to consult international financial organizations about the possibilities of investment in high technology and innovation. There is an important role for bodies such as the World Bank to help Russia to find ways in which it can tap into the bedrock of scientific talent which the country undoubtedly still possesses.

But the academy, too, must face up to the need for radical change. The academy's role as an arbiter of scientific excellence remains as important as ever. Less convincing is its continued conviction that it remains best placed to decide on the strategic distribution of scientific resources to meet the country's needs. Continued pressure from the government on the academy to adopt international standards and make tough resource decisions is needed. And continued international investment and collaborative scientific support from the West are required to help Russia tap the scientific talent that is now straining to express itself. 